Vol. 15 (2006): 12-22.

\title{
Formation of a cultivated Spodosol in East-Central Finland
}

\author{
Markku Yli-Halla \\ MTT Agrifood Research Finland, FI-31600 Jokioinen, Finland, Present address: Department of Applied Chemistry \\ and Microbiology, PO Box 27, FI-00014 University of Helsinki, Finland, e-mail: markku.yli-halla@helsinki.fi \\ Delbert L. Mokma \\ Department of Crop and Soil Sciences, Michigan State University, East Lansing, MI 48824, USA \\ Lawrence P. Wilding and L. Richard Drees \\ Department of Soil and Crop Science, Texas A\&M University, College Station, TX 77843, USA
}

\begin{abstract}
The processes involved in Spodosol (Podzol) formation are still being debated. The pedogenic processes in a Spodosol, 10,700 years-old, at Sotkamo that has been cultivated for about 50 years were studied by characterizing the morphology and analyzing the major chemical properties, texture and mineralogy. Before cultivation, organic acids produced by decomposition of organic matter from pine litter in $\mathrm{O}$ and $\mathrm{A}$ horizons had weathered primary minerals in $\mathrm{A}$ and $\mathrm{E}$ horizons releasing $\mathrm{Al}$ and $\mathrm{Fe}$. Percolating waters moved the organo-metallic complexes from A and E horizons to Bhsm and Bs horizons where the complexes coated and bridged sand grains eventually forming cemented ortstein. Because of the high biotite content of the parent material, the index of accumulation of $\mathrm{Fe}$ and $\mathrm{Al}$ in the Bhsm horizon $(\mathrm{Al}+0.5 \mathrm{Fe}=4.1 \%)$ was the highest reported in Spodosols of Finland. The data support the theory of downward movement of $\mathrm{Al}$ and $\mathrm{Fe}$ as organo-metallic complexes with formation of some ferrihydrite but little or no formation of imogolite type materials. Little, if any, podzolization has likely occurred since the initiation of cultivation because, after agricultural liming and consequent increase of $\mathrm{pH}$ in the Ap horizon, organic compounds are likely to chelate $\mathrm{Ca}$ and $\mathrm{Mg}$ rather than $\mathrm{Al}$ and $\mathrm{Fe}$.
\end{abstract}

Key words: podzolization, soil morphology, soil mineralogy, biotite, soil classification

\section{Introduction}

Spodosols (Soil Survey Staff 1999) or Podzols (FAO 1988, 1998) are an extensive group of soils in Finland, other Nordic countries and northern Rus- sia, especially in sandy parent materials and glacial till. Acidic parent materials, high leaching potentials, and acid litter from coniferous trees are conducive to podzolization of these soils. The low cation exchange capacities and low base status of sandy soils also enhance podzolization. Spodosols are 
Vol. 15 (2006): 12-22.

characterized by light-colored eluvial horizons with bleached, uncoated sand grains and a dark, reddishcolored illuvial horizon with accumulated organic matter and $\mathrm{Al}$ oxides with or without $\mathrm{Fe}$ oxides. Since Spodosols form mostly under forest vegetation, several studies have investigated the formation and characteristics of Spodosols in forested areas in Finland (Aaltonen 1952, Jauhiainen 1972, 1973, Starr 1991, Petäjä-Ronkainen et al. 1992, Gustafsson et al. 1995, Lundström et al. 2000, Righi et al. 1997, Mokma et al. 2004) however no comprehensive studies have focused on cultivated Spodosols.

Two main theories have been proposed for the mechanisms of podzolization. The older and more widely accepted theory is the downward movement of organo-metallic complexes from eluvial zones to illuvial zones where they exceed solubility limits and are precipitated (Stobbe and Wright 1959, DeConinck 1980). The illuvial organo-metallic compounds form polygonally cracked coatings on sand grains (monomorphic organic matter) (McKeague et al. 1983). Biological activity was thought to incorporate illuvial organo-metallic compounds into pellets (polymorphic organic matter). The more recently proposed theory involves the downward movement of $\mathrm{Al}, \mathrm{Fe}$ and $\mathrm{Si}$ as inorganic colloidal sols (Anderson et al. 1982, Farmer and Fraser 1982). A combination of the two theories has been proposed to explain formation of Spodosols in Nordic Countries (Gustafsson et al. 1995, Lundström et al. 2000). In this combination decomposition of organic matter in $\mathrm{O}$ and A horizons produces organic acids that weather primary minerals (Lundström et al. 1995, Raulund-Rasmussen et al. 1998) in A and E horizons thereby releasing Al, Fe, $\mathrm{Ca}, \mathrm{Mg}, \mathrm{K}$, and P. Plant uptake reduces the concentrations of nutrients, such as $\mathrm{Ca}, \mathrm{Mg}, \mathrm{K}$, and $\mathrm{P}$, however, plants take up very little $\mathrm{Al}, \mathrm{Fe}$ and $\mathrm{Si}$. Formation of organo-metallic complexes and their subsequent eluviation from $\mathrm{A}$ and $\mathrm{E}$ horizons was found to enhance weathering of primary minerals in those horizons (Lundström 1993). Microbial degradation of the organic portion of some complexes in Bhsm and $\mathrm{Bs}$ horizons caused some $\mathrm{Al}$ and $\mathrm{Fe}$ to precipitate as imogolite type materials and ferrihydrite, respectively, in some Nordic soils (Gustafsson et al. 1995). In these Spodosols ammonium oxalate ex- tractable $\mathrm{Al}$ and $\mathrm{Fe}$ exceeded sodium pyrophosphate $\mathrm{Al}$ and $\mathrm{Fe}$ in $\mathrm{B}$ horizons suggesting the presence of imogolite type materials and ferrihydrite. However, B horizons from 27 of 29 other Spodosols from several countries had equal or higher concentrations of pyrophosphate than oxalate extractable $\mathrm{Al}$, and B horizons from 25 of the 29 soils had equal or higher concentrations of pyrophosphate than oxalate extractable Fe (Mokma and Buurman 1982, Mokma and Vance 1989) suggesting the presence of little or no imogolite type materials and ferrihydrite in Spodosol B horizons. Two studies of podzols in the Netherlands found no evidence for the inorganic colloidal sols theory nor for the combination theory (Jansen et al. 2004, 2005). Organic matter facilitated mobilization of $\mathrm{Al}$ and $\mathrm{Fe}$ from eluvial horizons to illuvial horizons. As the organometallic complexes accumulated in B horizons sand grains were coated and bridged by them. As more organo-metallic complexes accumulated in B horizon the coatings and bridges got thicker eventually cementing sand grains into ortstein.

Earlier studies have shown that Spodosols of Finland formed in glacial till have weakly developed E and Bhs horizons (Mount et al. 1995, Mokma et al. 2000, Yli-Halla and Mokma 2001) and these soils only marginally meet the criteria of Spodosols. By contrast, Spodosol formation in sand has resulted in more pronounced development of the horizons (Mokma et al. 2004). In the Sotkamo area, even ortstein has been found. In order to study the soil forming processes taking place in a cultivated soil in an advanced state of podzolization, a 10,700 years old pedon, in agricultural use for 50 years, at Sotkamo was characterized in detail. Support for either of the main theories of the podzolization process was sought for. This study also adds to the few published descriptions of cultivated coarse-textured pedons of Finland.

\section{Material and methods}

A sandy soil was selected for study in an area used for raising potatoes, ley and small grains at Sotka- 
mo, East-Central Finland. The field $\left(64^{\circ} 07^{\prime} \mathrm{N}, 28^{\circ}\right.$ $20^{\prime}$ E) is located on the Kainuu Research Station, belonging to the MTT Agrifood Research Finland organization. The soil is about 10,700 years old, and thus represents close to the maximum time available for soil formation in Finland after the Weichselian glaciation. The native vegetation was Scotch pine (Pinus sylvestris). Three pits, in an area of $50 \mathrm{~m} \times 50 \mathrm{~m}$, were dug (two in 1999 and one in 2001) to facilitate describing the macromorphology and to obtain samples for laboratory analyses and micromorphological investigation. The depth to ground water was $189 \mathrm{~cm}$ on 10 August 1999 and $160 \mathrm{~cm}$ on 6 July 2001. The pits were morphologically similar, and the one dug in 2001 was studied for this paper. Organic C was determined using the Leco dry combustion apparatus (Laboratory Equipment, St. Joseph, MI). Soil pH was measured in water at a 1:2.5 soil to water ratio. $\mathrm{Al}$ and $\mathrm{Fe}$ were extracted with sodium citrate sodium dithionite, ammonium oxalate ( $\mathrm{pH} 3.0)$, and sodium pyrophosphate (Soil Survey Staff 1996). Silicon (Si) was also measured in the oxalate extract. The optical density of the oxalate extract (ODOE) was measured as an indicator of organic $\mathrm{C}$ associated with amorphous materials. Cation exchange capacity (CEC) was determined by extracting soil samples with four portions of 1 $\mathrm{M}$ ammonium acetate $(\mathrm{pH}$ 7.0) and analyzed for $\mathrm{Ca}, \mathrm{Mg}, \mathrm{K}$ and $\mathrm{Na}$. Titratable acidity was determined by titrating the extract back to $\mathrm{pH} 7.00$ with $0.02 \mathrm{M} \mathrm{NaOH}$. The CEC was calculated as the sum of $\mathrm{Ca}, \mathrm{Mg}, \mathrm{K}, \mathrm{Na}$ and titratable acidity, all expressed as cmol(+) $\mathrm{kg}^{-1}$. Particle size distribution was determined using the pipette method after digestion with hydrogen peroxide. Bulk density, expressed on the basis of dry soil, was determined by the clod method (Brasher et al. 1966) using Saran resin to stabilize the clods.

Oriented samples for micromorphological examinations were collected from selected horizons using $8 \times 16 \times 5 \mathrm{~cm}$ Kubiëna tins. Samples were impregnated under vacuum (Ashley 1973) using a polyester resin diluted 2:1 with acetone. Hardening of the resin was accomplished using $8 \times 10^{6}$ Rad gamma radiation (Drees and Drees 1997). Vertically oriented soil thin sections $(40 \times 60 \mathrm{~mm})$ were prepared from each sample. Sample blocks were polished, mounted on glass slides with epoxy and ground to a final thickness of $30 \mu \mathrm{m}$ and described using the terminology of Bullock et al. (1985) and Stoops (2003).

Mineralogical composition of the sand (0.05-2 $\mathrm{mm})$, silt $(2-50 \mu \mathrm{m})$ and clay $(<2 \mu \mathrm{m})$ fractions was determined in three horizons (E, Bhsm, BCg) on a semi-quantitative basis by $\mathrm{X}$-ray diffraction using $\mathrm{Cu} \mathrm{K} \alpha$ radiation with a Philips X-ray diffractometer (XRD). Small amounts of clay recovered from the Bhsm horizon prevented its clay mineralogical examination. The clay suspensions were flocculated with $0.5 \mathrm{M} \mathrm{MgC1}_{2}$. After washing the clays free of salts they were sedimented on ceramic-tile plates via suction. A sufficiently thick clay film (about $26 \mathrm{mg}$ clay $\mathrm{cm}^{-2}$ plate area) was deposited on each tile to prevent any diffraction spectra from the ceramic tile.

Pretreatments used for $\mathrm{Mg}$-saturated clays were air dry, ethylene glycol, and $350^{\circ} \mathrm{C}$ and $550^{\circ} \mathrm{C}$ heat treatments. Heated samples were maintained at respective temperatures for at least 2 hours before analysis. Clays were scanned from $2^{\circ} 2 \theta$ to $32^{\circ} 2 \theta$ at a scan speed of $2^{\circ} 2 \theta \mathrm{min}^{-1}$. The sands $(0.05-2 \mathrm{~mm})$ and silts $(2-50 \mu \mathrm{m})$ were ground for one minute in a disc mill grinder to reduce particle size. The powder was then front loaded into aluminum box mounts for X-ray analysis and scanned from $2^{\circ} 2 \theta$ to $50^{\circ} 2 \theta$ at a scan speed of $2^{\circ} 2 \theta \mathrm{min}^{-1}$. Minerals were identified according to Brown and Brindley (1984).

The pedon was classified according to Soil Taxonomy (Soil Survey Staff 1999), the FAOUnesco system (FAO 1988) and the World Reference Base for Soil Resources system (WRB) (FAO 1998). We assumed the pedon has a cryic soil temperature regime (Yli-Halla and Mokma 1998).

\section{Results and discussion}

\section{Macromorphology}

The sandy over loamy pedon had a typical Spodosol morphology with a gray colored $\mathrm{E}$ horizon 
Vol. 15 (2006): 12-22.

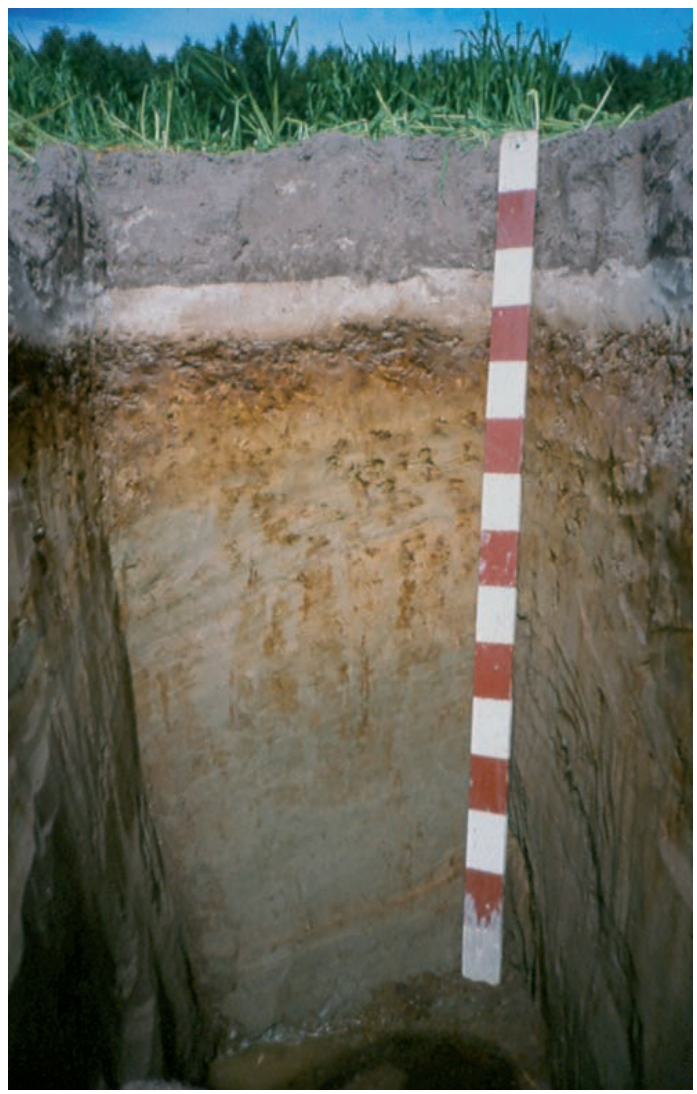

Fig. 1. Photo of pedon. The E horizon is more continuous and the lower boundary is less wavy in this part of the pit. Units on scale are $10 \mathrm{~cm}$. (Photo: M. Yli-Halla.) and dark, reddish brown colored B horizons (Fig. 1, Table 1). This color pattern suggests organic matter, $\mathrm{Al}$ and $\mathrm{Fe}$ have been translocated in this pedon from the surface horizons to subsoils where in the Bhsm they have cemented the sand grains together into ortstein. In the Bhsm horizon, the ortstein was not continuously cemented but consisted mostly of medium-sized platy chunks stacked vertically together. Firm chunks of 2.5 YR $2.5 / 2$ ortstein were also present in the Bs horizon indicating elevated levels of organic $\mathrm{C}, \mathrm{Al}$ and Fe have accumulated in these parts of the Bs horizon.

The pit had a circumference of $762 \mathrm{~cm}$, with the E horizon present in $364 \mathrm{~cm}$ or about $48 \%$ of the pit wall. In $52 \%$ of the pit wall the Ap horizon was in contact with the Bhsm horizon without an $\mathrm{E}$ horizon between them. The discontinuous nature of the E horizon in this pedon is the result of cultivation. The $\mathrm{E}$ horizon remaining was in the deeper portions of the wavy boundary that extend below the depth of plowing. The two other pits investigated in this field earlier had a continuous E horizon. An uncultivated Spodosol pedon, located $1400 \mathrm{~m}$ from the pedon of this study, had an $8 \mathrm{~cm}$ thick $\mathrm{O}$ horizon and a $26 \mathrm{~cm}$ thick continuous $\mathrm{E}$ horizon with a wavy boundary over a Bhsm horizon (Mokma et al. 2004). The wavy boundaries between the $\mathrm{E}$, Bhsm, Bs, BC, $\mathrm{BCg}$ and $\mathrm{Cg}$ horizons are likely the result of preferential water flow

Table 1. Morphological properties of the pedon.

\begin{tabular}{|c|c|c|c|c|c|c|}
\hline Horizon & Depth, cm & Color, matrix & Color, mottles & Texture & Structure & Boundary \\
\hline Ap & $0-25$ & $\begin{array}{c}\text { 10YR 3/2 } \\
\text { 10YR 6/1 dry }\end{array}$ & & ls & $1 \mathrm{msbk}$ & as \\
\hline $\mathrm{E}$ & $25-37$ & $\begin{array}{c}\text { 10YR 6/2 } \\
10 \text { YR } 8 / 2 \text { dry }\end{array}$ & & ls & 0sg & $a b$ \\
\hline Bhsm & $37-46$ & $2.5 \mathrm{YR} 2.5 / 2$ & & $\mathrm{~s}$ & $0 \mathrm{~m} / 2 \mathrm{mpl}$ & aw \\
\hline Bs & $46-61$ & 10YR 5/6 & & $\mathrm{s}$ & $1 \mathrm{msbk}$ & aw \\
\hline $\mathrm{BC}$ & 61-104 & $2.5 Y 6 / 3$ & c2p 7.5YR 4/4 & fs & $1 \mathrm{mpl}$ & as \\
\hline $\mathrm{BCg}$ & $104-160$ & $2.5 Y 5 / 2$ & $\mathrm{c} 2 \mathrm{p} 7.5 \mathrm{YR} 4 / 4$ & fsl \& sil & $1 \mathrm{mpl}$ & as \\
\hline $\mathrm{Cg}$ & $160-193$ & $2.5 Y 5 / 2$ & c3p10YR 4/6 & fsl \& sil & $1 \mathrm{fpl}$ & \\
\hline
\end{tabular}

Color, mottles: $\mathrm{c}=$ common (mottling $2-20 \%), 2=$ medium $(5-15 \mathrm{~mm}), 3=$ large $(>15 \mathrm{~mm}), \mathrm{p}=$ prominent

Texture: $1 \mathrm{~s}=$ loamy sand, $\mathrm{s}=$ sand, $\mathrm{fs}=$ fine sand, fsl = fine sandy loam, sil = silt loam

Structure: $0=$ structureless, $1=$ weak, $2=$ moderate, $\mathrm{m}=$ medium, $\mathrm{f}=$ fine, $\mathrm{sg}=$ single-grain, sbk $=$ subangular blocky, $\mathrm{pl}=$ platy

Boundary: as = abrupt smooth, $\mathrm{ab}=$ abrupt broken, $\mathrm{aw}=$ abrupt wavy 
through differentially permeable sandy and loamy materials.

Plowing and secondary tillage have mixed materials from the $\mathrm{O}, \mathrm{A}, \mathrm{E}$ and Bhsm horizons into the Ap horizon. Chunks of ortstein from the Bhsm and white sand grains from the $\mathrm{E}$ horizon where observed in the Ap horizon. The origin of these chunks of ortstein is the Bhsm horizon that is currently in contact with the Ap horizon. The amount of $\mathrm{B}$ horizon material was much less than 85 percent, a criterion for a spodic horizon. The cementation in the Bhsm horizon was sufficient to resist complete breakdown by tillage.

The platy structure in the $\mathrm{BC}$ and $\mathrm{C}$ horizons (Table 1) resulted from the fluvial deposition of the original sandy parent materials. Rock structure was observed in thin sections of the $\mathrm{BC}, \mathrm{BCg}$ and $\mathrm{Cg}$ horizons but not in the Ap, E, Bhsm and Bs horizons. Pedogenic processes have altered the structure in the upper horizons.

\section{Chemical characteristics}

Organic C was greatest in the Ap horizon, least in the $\mathrm{E}$ and $\mathrm{Cg}$ horizons and intermediate in the $\mathrm{B}$ horizons (Table 2). Dry bulk density was inversely related to the organic $\mathrm{C}$ contents of the horizons.
Cation exchange capacity was related to the organic $\mathrm{C}$ content. However, the highest value was measured in the Bhsm horizon in spite of the fact that the Ap horizon had a higher content of organic C. The high CEC is primarily the result of the amorphous material that accumulated in the Bhsm having a high CEC. Distributions of Al, Fe and organic $\mathrm{C}$ as indicated by ODOE (Table 3 ) support the interpretation of the macromorphology. The index of the accumulation of $\mathrm{Al}$ and $\mathrm{Fe}\left(\mathrm{Al}_{\mathrm{o}}+1 / 2\right.$ $\mathrm{Fe}_{\mathrm{o}}$ ) greatly exceeded the $0.5 \%$ minimum value set for spodic materials in the Bhsm horizon, whereas it was slightly exceeded in the $\mathrm{Bs}$ horizon. The $\mathrm{Al}_{\text {o }}$ $+1 / 2 \mathrm{Fe}_{0}$ value of $4.1 \%$ in the Bhsm horizon is the highest that has been reported in Finland, particularly attributable to the very high concentration of $\mathrm{Fe}_{\mathrm{o}}$ in this soil. The $\mathrm{Al}_{\mathrm{o}}$ content of the Bhsm horizon is similar to that of the Bhs and Bhsm horizons in other studies of Spodosols in Finland (e.g. Righi et al. 1997, Mokma et al. 2004) but the Fe content is much greater. Also the concentration of organic $\mathrm{C}(>>0.6 \%)$ and $\mathrm{pH}(<<5.9)$ in the Bhsm and Bs horizons and the ODOE ( $>>0.25)$ of the Bhsm horizon meet the criteria of spodic materials. The very low $\mathrm{Fe}_{\mathrm{o}}$ concentrations in the $\mathrm{BCg}$ and $\mathrm{Cg}$ horizons may be attributable to illuvial materials not reaching these depths and to periodically watersaturated conditions.

Table 2. Selected physical and chemical properties of pedon. Sand, silt and clay indicate particles of 2-0.06 mm, 0.06$0.002 \mathrm{~mm}$ and $<0.002 \mathrm{~mm}$, respectively.

\begin{tabular}{lccccccrr}
\hline Horizon & $\begin{array}{c}\text { Sand } \\
\%\end{array}$ & $\begin{array}{c}\text { Silt } \\
\%\end{array}$ & $\begin{array}{c}\text { Clay } \\
\%\end{array}$ & $\begin{array}{c}\text { Bulk density } \\
\mathrm{kg} \mathrm{dm}^{-3}\end{array}$ & $\mathrm{pH}^{2)}$ & $\begin{array}{c}\text { Org. } \mathrm{C}^{3)} \\
\%\end{array}$ & $\begin{array}{c}\mathrm{CEC}^{4)} \\
\mathrm{cmol}^{(+)} \mathrm{kg}^{-1}\end{array}$ & $\begin{array}{c}\left.\mathrm{BS}^{5}\right) \\
\%\end{array}$ \\
\hline Ap & 83 & 15 & 2 & 1.30 & 5.7 & 4.3 & 13.5 & 51 \\
E & 83 & 16 & 1 & nd & 5.8 & 0.2 & 2.6 & 32 \\
Bhsm & 91 & 7 & 2 & 1.33 & 4.8 & 2.9 & 20.9 & 8 \\
Bs & 99 & 1 & 0 & 1.48 & 5.3 & 1.3 & 6.1 & 11 \\
BC & 93 & 7 & 0 & 1.68 & 4.8 & 0.3 & 4.3 & 7.5 \\
BCg & 42 & 57 & 1 & 1.68 & 5.1 & 0.4 & nd & nd \\
Cg & 51 & 49 & 0 & nd & 5.0 & 0.1 & &
\end{tabular}

1) bulk density of dry soil, standard deviation of the three replicates is $0.04 \mathrm{~kg} \mathrm{dm}^{-3}$.

2) Average mean deviation of the two replicates 0.09

3) Long-time coefficient of variation of the results of a control sample $4.1 \%$

${ }^{4)} \mathrm{CEC}=$ cation exchange capacity. Average mean deviation of the two replicates $0.13 \mathrm{cmol}(+) \mathrm{kg}^{-1}$

${ }^{5)} \mathrm{BS}=$ base saturation

nd $=$ not determined 
Vol. 15 (2006): 12-22.

Table 3. Aluminum, iron and silicon, extracted with citrate-dithionite $\left(\mathrm{Al}_{\mathrm{d}}, \mathrm{Fe}_{\mathrm{d}}\right)$, ammonium oxalate $\left(\mathrm{Al}_{\mathrm{o}}, \mathrm{Fe}_{\mathrm{o}}, \mathrm{Si}_{\mathrm{o}}\right)$ and sodium pyrophosphate $\left(\mathrm{Al}_{\mathrm{p}}, \mathrm{Fe}_{\mathrm{p}}\right)$ and the optical density of oxalate extract (ODOE) values.

\begin{tabular}{lccccccccc}
\hline Horizon & $\mathrm{Al}_{\mathrm{d}}$ & $\mathrm{Al}_{\mathrm{o}}$ & $\mathrm{Al}_{\mathrm{p}}$ & $\mathrm{Fe}_{\mathrm{d}}$ & $\mathrm{Fe}_{\mathrm{o}}$ & $\mathrm{Fe}_{\mathrm{p}}$ & $\mathrm{Al}_{\mathrm{o}}+1 / 2 \mathrm{Fe}_{\mathrm{o}}$ & $\mathrm{Si}_{\mathrm{o}}$ & $\mathrm{ODOE}$ \\
\hline $\mathrm{Ap}$ & nd & 0.11 & nd & nd & 0.36 & nd & 0.29 & 0.017 & 0.14 \\
$\mathrm{E}$ & 0.02 & 0.02 & 0.02 & 0.04 & 0.01 & 0.02 & 0.02 & 0.001 & 0.03 \\
$\mathrm{Bhsm}$ & 0.87 & 0.96 & 0.74 & 7.02 & 6.24 & 2.63 & 4.08 & 0.130 & 1.37 \\
$\mathrm{Bs}$ & 0.42 & 0.42 & 0.40 & 0.48 & 0.33 & 0.22 & 0.59 & 0.069 & 0.20 \\
$\mathrm{BC}$ & nd & 0.12 & nd & nd & 0.18 & nd & 0.21 & 0.024 & 0.05 \\
$\mathrm{BCg}$ & nd & 0.14 & nd & nd & 0.02 & nd & 0.15 & 0.022 & 0.05 \\
$\mathrm{Cg}$ & nd & 0.08 & nd & nd & 0.01 & nd & 0.08 & 0.017 & 0.02 \\
$\mathrm{Md}, \%$ & 5.4 & 3.2 & 4.6 & 5.6 & 5.5 & 3.4 & 6.9 & 6.3 & 3.3 \\
\hline
\end{tabular}

nd $=$ not determined

$\mathrm{Md}=$ average mean deviation of the results of the two replicates, as percentage of the mean.

Most (77\%) of the $\mathrm{Al}_{\mathrm{o}}$ in the Bhsm horizon and all in the Bs horizon was extracted by sodium pyrophosphate. Therefore most of the Al was chelated with organic matter (McKeague et al. 1971) with some possible imogolite type materials in the Bhsm horizon. However, the $\mathrm{Al}_{\mathrm{o}}-\mathrm{Al}_{\mathrm{p}} / \mathrm{Si}_{\mathrm{o}}$ ratios of the Bhsm and Bs horizons were 0.17 and 0.03 , respectively, indicating little imogolite type material that has an $\mathrm{Al}_{\mathrm{o}}-\mathrm{Al}_{\mathrm{p}} / \mathrm{Si}_{\mathrm{o}}$ ratio of about 2 (Anderson et al. 1982) was present in the $\mathrm{B}$ horizons. Most of the $\mathrm{Fe}_{\mathrm{d}}$ in the B horizons (89\% in Bhsm and 69\% in Bs) was extracted by ammonium oxalate. Therefore it was chelated by organic matter or was amorphous ferrihydrite but not highly crystalline. About $42 \%$ of the $\mathrm{Fe}_{\mathrm{o}}$ in the Bhsm horizon and $67 \%$ of that in the Bs horizon was extractable by pyrophosphate. This suggests $\mathrm{Al}$ and $\mathrm{Fe}$ were chelated by organic compounds in the A and $\mathrm{E}$ horizons and transported to the $\mathrm{B}$ horizon by percolating waters. In the B horizon some of the organometallic complexes may have been degraded by microbial activity and the Fe precipitated as ferrihydrite. The likely source of Fe accumulated in the Bhsm horizon is the biotite that was present in the lower horizon but completely weathered in the upper horizons.

\section{Micromorphology}

Sand grains in the Ap (Fig. 2a) and E (Fig. 2b) horizons did not have coatings or bridges except for several chunks of Bhsm materials that had been mixed into the Ap horizon. Organo-metallic complexes, imogolite type materials, and ferrihydrite coated sand grains and formed bridges between sand grains in the Bhsm (Fig. 2c and 2d) and Bs (Fig. 2e) horizons. The coatings and bridges in the Bhsm horizon thickened and cemented nearly all sand grains together (Fig. 2d). The coatings appeared to protect some weatherable mineral grains in the Bhsm horizon. The $\mathrm{BCg}$ horizon had few $\mathrm{Al}$ and Fe coatings and many weatherable minerals (Fig. 2f).

\section{Mineralogy}

Even though the $\mathrm{BCg}$ and $\mathrm{Cg}$ horizons have more silt than the upper horizons (Table 2), we assumed that the solum had been mineralogically rather homogeneous at the beginning of soil formation. According to the XRD analyses, all sand and siltsized chlorite and mica had weathered completely in the E and Bhsm horizons (Table 4). From thinsection analysis the mica was identified as biotite (Fig. 2f), which ideally has a Fe content of about $6 \%$. Most of the biotite was present in the $\mathrm{BCg}$ horizons but was not observed in Ap and E horizons, presumably because it had weathered out of these eluvial horizons. This may explain the presence of ferrihydrite in the B horizon and the high index of accumulation in this pedon. Some silt and clay-sized amphibole had weathered in the E hori- 

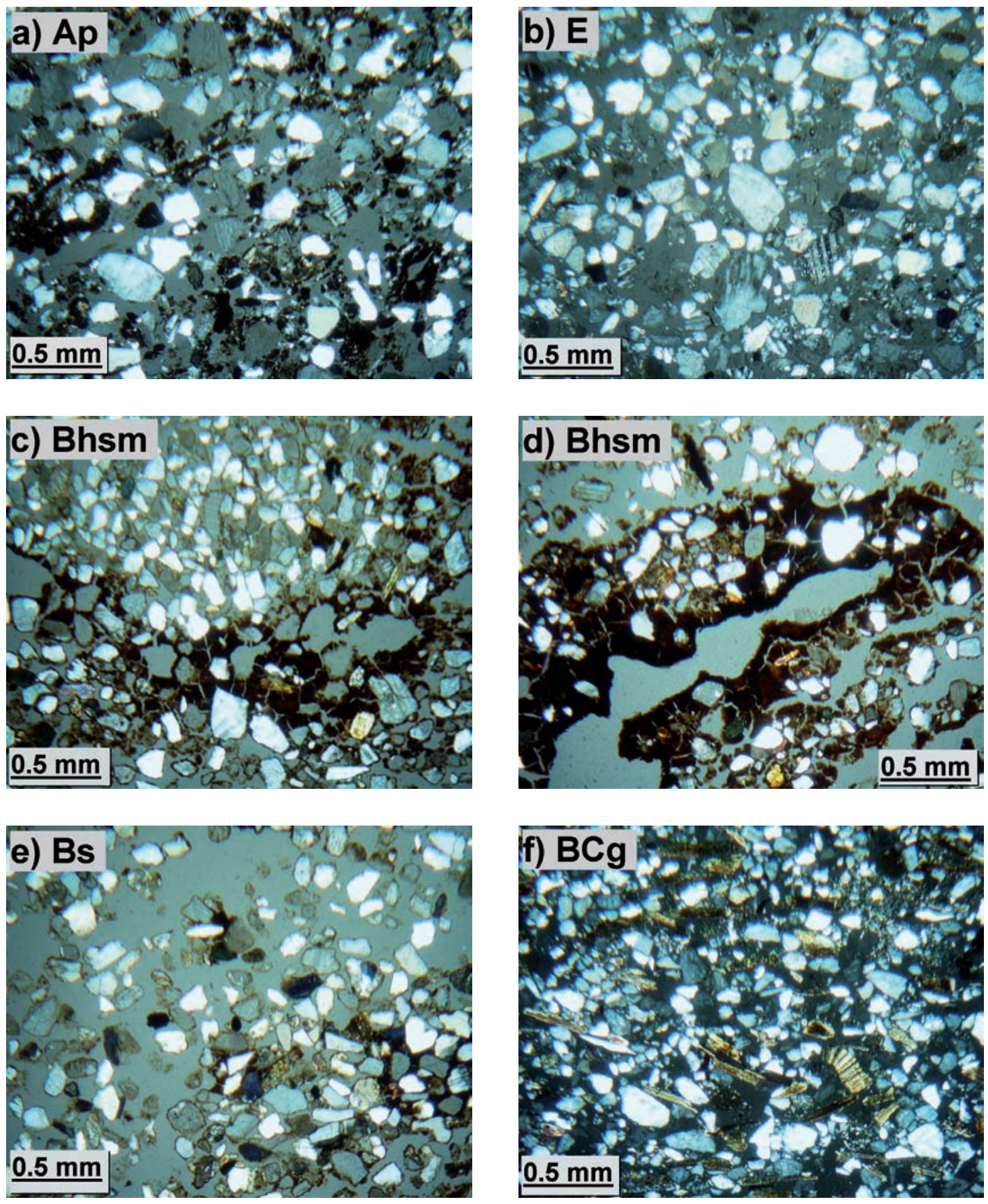

Fig. 2. Micrographs of select micromorphological features in selected horizons. (a) organic particles and uncoated sand grains in Ap horizon, (b) uncoated sand grains in E horizon, (c) sand grains cemented by complexes in Bhsm horizon, (d) cracked coatings bridging sand grains in Bhsm horizon, (e) thin coatings on sand grains in Bs horizon, and (f) relatively unweathered and uncoated sand grains and plenty of biotite (brown) in BCg horizon. Photos taken in partially polarized light mode (half cross-polarized light). (Micrographs by the entire research group.) 
Vol. 15 (2006): 12-22.

Table 4. Semiquantative mineralogical composition $(+=$ least abundant, $+++=$ most abundant $)$ of sand, silt and clay fractions of selected horizons.

\begin{tabular}{|c|c|c|c|c|c|c|c|}
\hline Horizon & Quartz & Feldspar & Amphibole & Pyroxene & Chlorite & Mica & Vermiculite \\
\hline \multicolumn{8}{|l|}{ Sand } \\
\hline $\mathrm{E}$ & +++ & +++ & + & + & & & \\
\hline Bhsm & +++ & +++ & & & & & \\
\hline $\mathrm{BCg}$ & +++ & +++ & + & & + & + & \\
\hline \multicolumn{8}{|l|}{ Silt } \\
\hline E & +++ & +++ & + & + & & & \\
\hline Bhsm & +++ & +++ & & + & & & \\
\hline $\mathrm{BCg}$ & +++ & +++ & + & + & + & + & \\
\hline \multicolumn{8}{|l|}{ Clay } \\
\hline E & +++ & ++ & + & & + & + & + \\
\hline $\mathrm{BCg}$ & +++ & ++ & + & & ++ & + & + \\
\hline
\end{tabular}

zon. Regularly interstratified vermiculite and biotite was present in the clay fraction of the $\mathrm{BCg}$ horizon but not in the E horizon. The irregular interstratified vermiculite and biotite suggests some of the biotite in the E horizon had weathered to vermiculite. The presence of a $1.54 \AA 060$ diffraction peak and the absence of a $1.49 \AA 060$ peak indicated chlorite and not kaolinite was present (Moore and Reynolds 1989). The mineralogy is similar to that presented earlier for coarse-textured soils in Finland (Mokma et al. 2004), quartz and feldspars being the dominant minerals. In the Bs 3 horizon of the uncultivated Spodosol of Sotkamo, allophane was also detected (Mokma et al. 2004). The clay mineralogy of the $\mathrm{E}$ horizon of this pedon lacked smectite. This is different from two Spodosols chronosequences (up to 10,000 years old) in Finland, studied by Righi et al. (1997) and Gillot et al. (1999). The clay minerals in this pedon were dominantly trioctahedral (060 spacing of $1.54 \AA$ ). The smectite found in E horizons of other Spodosols in Finland was identified as dioctahedral (Righi et al. 1997, Gillot et al. 1999). All fine clay fractions were dioctahedral (Righi et al. 1997) indicating the parent material mineralogy of the tills in central Finland (Righi et al. 1977) is different from that of the pedon in this study. This may explain the lack of smectite in the E horizon of this pedon.

\section{Cultivation-induced changes}

Cultivation has likely terminated or certainly slowed podzolization in this pedon. $\mathrm{Al}$ and $\mathrm{Fe}$ are soluble and available for chelation under very acid conditions, $<5.5$, but not when the soils have been limed above this reaction. When the soil was cleared for agriculture, the trees and bushes were removed and $\mathrm{Ca}$ and $\mathrm{Mg}$ were added through liming, fertilization and manuring. Indeed, the Ap and even the E horizon had a higher $\mathrm{pH}$ and base saturation than the horizons below (Table 2). Lower $\mathrm{pH}$ values, between 3.5 and 4.5, are also typical for the E horizons of native Spodosols of Finland and a base saturation (BS) of only $8 \%$ has been found (Mokma et al. 2000, 2004). Particularly, the high values measured in the $\mathrm{E}$ horizon $(\mathrm{pH} \mathrm{5.8,} \mathrm{BS}$ $32 \%$ ) contrast with the E horizon of the forested Spodosol close by ( $\mathrm{pH} 4.3$ ), being the most acidic horizon in that entire pedon, indicating neutralizing components have been translocated downwards from the Ap horizon. Organic compounds which chelate $\mathrm{Al}$ and $\mathrm{Fe}$ will also chelate divalent cations such as $\mathrm{Ca}$ forming relatively insoluble calcium humates (McKeague et al. 1983, p. 241). The organic compounds that are produced by decomposition of organic matter in the Ap horizon, and would naturally chelate $\mathrm{Al}$ and $\mathrm{Fe}$, will chelate 
the added $\mathrm{Ca}$ and $\mathrm{Mg}$, whereas the $\mathrm{Al}$ and Fe remain in the Ap and E horizons. Small amounts of $\mathrm{Ca}$ will cause $\mathrm{Al}$ and $\mathrm{Fe}$ complexes to precipitate (Mokma and Buurman 1982, p. 5). The short period of cultivation, 50 years, has had little impact on the properties of this pedon. Cultivated Spodosols in Poland and Michigan, USA had less Al and $\mathrm{Fe}$ in Bhs and Bs horizons than nearby uncultivated Spodosols (Mokma and Szafranek 2001) indicating podzolization process were slowed or possibly terminated by cultivation.

\section{Classification}

According to Soil Taxonomy (Soil Survey Staff 1999) an albic or E horizon must be present in $50 \%$ or more of the pedon in order to qualify as a Spodosol. The pedon, studied in detail, had an albic horizon only in $48 \%$ percent of the pedon. Therefore, it did not quite meet the criteria for a spodic horizon (Soil Survey Staff 1999). The sand-textured Bhsm and Bs horizon did not meet the textural criteria for a cambic horizon. As a result, the pedon was classified as a Spodic Cryopsamment. If the albic horizon was in at least $50 \%$ of the pedon, like in the two other pedons of the same field and in an uncultivated otherwise similar pedon 1.4 $\mathrm{km}$ away, the pedon would be classified as Typic Duricryods. This subgroup was previously thought to not likely occur in Finland (Mokma and YliHalla 2000). According to the FAO system (FAO 1988) the pedon was classified as Haplic Podzols. The pedon was classified as Duric Podzols according to the WRB system (FAO 1998).

\section{Conclusions}

Before cultivation of the pedon in this study, organic acids produced by decomposition of organic matter from pine litter in $\mathrm{O}$ and $\mathrm{A}$ horizons had weathered primary minerals in A and $\mathrm{E}$ horizons releasing $\mathrm{Al}$ and $\mathrm{Fe}$. Organic compounds chelated the $\mathrm{Al}$ and $\mathrm{Fe}$ and percolating waters translocated the organo-metallic complexes to the Bhsm and Bs horizons. Degradation of some of the complexes by microbial activity may have caused some Fe to precipitate as ferrihydrite, but little if any imogolite type materials formed. Weathering of biotite has likely contributed to the abundance of ferrihydrite. The $\mathrm{Al}$ and $\mathrm{Fe}$ complexes coat and bridge sand grains and eventually cemented the sand grains into ortstein. The data from the pedon in this study appear to support the older and more widely accepted theory of podzolization.

After initiation of cultivation of the pedon the $\mathrm{O}, \mathrm{A}, \mathrm{E}$ and parts of the Bhsm horizon were mixed into an Ap horizon. Organic compounds produced through decomposition of cultivated crop residues are not likely to chelate and translocate $\mathrm{Al}$ and $\mathrm{Fe}$ because they are not highly acidic and the $\mathrm{pH}$ has been elevated by liming. Any organic compounds that might be able to chelate $\mathrm{Al}$ and $\mathrm{Fe}$ will chelate, instead, $\mathrm{Ca}$ and $\mathrm{Mg}$ added by liming, fertilization and manuring. Therefore little, if any, further podzolization will occur as long as the study area is cultivated.

Acknowledgement. The authors thank Mr. Pekka Heikkinen and Mr. Jukka Kemppainen for technical assistance in field work and the staff of the soil laboratory of MTT Agrifood Research Finland for carrying out the chemical and physical analyses.

\section{References}

Aaltonen, V.T. 1952. Soil formation and soil types. Fennia 72: 65-73.

Anderson, H.A., Berrow, M.L., Farmer, V.C., Hepburn, A., Russell, J.D. \& Walker, A.D. 1982. A reassessment of podzols formation processes. Journal of Soil Science 33: 125-136.

Ashley, G.H. 1973. Impregnation of fine-grained sediments with a polyester resin: a modification of Altmuller's method. Journal of Sedimentary Petrology 43: 298301.

Brasher, B.R., Franzmeier, D.P., Valassis, V. \& Davidson, E. 1966. Use of Saran resin to coat natural soil clods for bulk-density and water-retention measurements. Soil Science 101: 108.

Brown, G. \& Brindley, G.W. 1984. X-ray diffraction procedures for clay mineral identification. In: Brindley, G.W. \& Brown, G. (eds.). Crystal structures of clay minerals 
Vol. 15 (2006): 12-22.

and their X-ray identification. Mineralogical society Monograph, vol. 5. Spottiswoods Ballantyne, Colchester. p. 305-359.

Bullock, P., Federoff, N., Jongerius, A., Stoops, G. \& Tursina, T. 1985. Handbook for soil thin section description. Waine Research Publications. Wolverhampton, UK. $152 \mathrm{p}$.

DeConinck, F. 1980. Major mechanisms in formation of Spodic horizons. Geoderma 24: 101-128.

Drees, L.R. \& Drees, L.D. 1997. Nuclear reactor irradiation to polymerize resin impregnated samples. Agronomy Abstracts. p. 308.

FAO 1988. FAO-Unesco soil map of the world. Revised legend. World Soil Resources Report 60. FAO, Rome. Reprinted as Technical Paper 20, International Soil Reference and Information Centre, Wageningen. 144 p.

FAO 1998. World Reference Base for Soil Resources. World Soil Resources Report 84. FAO, Rome. 88 p.

Farmer, V.C. \& Fraser, A.R. 1982. Chemical and colloidal stability of sols in the $\mathrm{Al}_{2} \mathrm{O}_{3}-\mathrm{Fe}_{2} \mathrm{O}_{3}-\mathrm{SiO}_{2}-\mathrm{H}_{2} \mathrm{O}$ system: their role in podzolization. Journal of Soil Science 33: 737-742.

Gillot, F., Righi, D. \& Räisänen, M.L. 1999. Formation of smectites and their alteration in two chronosequences of podzols in Finland. In: Kodama, H. et al. (eds.). Clays for our future. Proceedings of the 11th International Clay Conference Ottawa, Canada, 15-21 June 1997. p. 725-731.

Gustafsson, J.P., Bhattacharya, P., Bain, D.C., Fraser, A.R. \& McHardy, W.J. 1995. Podzolisation mechanisms and the synthesis of imogolite in northern Scandinavia. Geoderma 66: 167-184.

Jansen, B., Nierop, K.G.J. \& Verstraten, J.M. 2004. Mobilization of dissolved organic matter, aluminum and iron in podzol eluvial horizons as affected by formation of metal-organic complexes and interactions with solid soil material. European Journal of Soil Science 55: 287-297.

Jansen, B., Nierop, K.G.J. \& Verstraten, J.M. 2005. Mechanisms controlling the mobility of dissolved organic matter, aluminium and iron on podzol B horizons. European Journal of Soil Science 56: 537-550.

Jauhiainen, E. 1972. Rate of podzolization in a dune in northern Finland. Societas Scientiarum Fennica. Commentationes Physico-Mathematicae 42: 33-44.

Jauhiainen, E. 1973. Age and degree of podzolization of sand soils on the coastal plain of northwest Finland. Societas Scientiarum Fennica. Commentationes Biologicae 68: 1-32.

Lundström, U.S. 1993. The role of organic acids in the soil solution chemistry of a podzolized soil. Journal of Soil Science 44: 121-133.

Lundström, U.S., van Breeman, N. \& Jongmans, A.J. 1995. Evidence for microbial decomposition of organic acids during podzolization. European Journal of Soil Science 46: 489-496.

Lundström, U.S., van Breeman, N., Bain, D.C., van Hees, P.A.W., Giesler, R., Gustafsson, J.P., Ilvesniemi, H., Karltun, E., Melkerud, P.-A., Olsson, M., Riise, G., Wahlberg, O., Bergelin, A., Bishop, K., Finlay, R., Jongmans, A.G., Magnusson, T., Mannerkoski, H., Nordgren, A., Nyberg, L., Starr, M. \& Tau Strand, L. 2000.
Advances in understanding the podzolization process resulting from a multidisciplinary study of three coniferous forest soils in the Nordic Countries. Geoderma 94: 335-353.

McKeague, J.A., Brydon, J.E. \& Miles, N.M. 1971. Differentiation of forms or extractable iron and aluminum in soils. Soil Science Society of America Proceedings 35: 33-38.

McKeague, J.A., DeConinck, F. \& Franzmeier, D.P. 1983. Spodosols. In: Wilding, L.P. et al. (eds.). Pedogenesis and soil taxonomy II. The soil orders. Elsevier, New York, NY. p. 217-252.

Mokma, D.L. \& Buurman, P. 1982. Podzols and podzolization in temperate regions. International Soil Museum, Wageningen, the Netherlands. $126 \mathrm{p}$.

Mokma, D.L. \& Szafranek, A. 2001. Sustainable crop production of Spodosols in Michigan, United States of America, and Poland. Soil Survey Horizons 42: 4-10.

Mokma, D.L. \& Vance, G.F. 1989. Forest vegetation and origin of some spodic horizons, Michigan. Geoderma 43: 311-324.

Mokma, D.L. \& Yli-Halla, M. 2000. Keys to soil taxonomy for Finland. United States Department of Agriculture, Natural Resources Conservation Service. $31 \mathrm{p}$.

Mokma, D.L., Yli-Halla, M. \& Hartikainen, H. 2000. Soils in a young landscape on the coast of southern Finland. $\mathrm{Ag}$ ricultural and Food Science in Finland 9: 291-302.

Mokma, D.L., Yli-Halla, M. \& Lindqvist, K. 2004. Podzol formation in sandy soils of Finland. Geoderma 120: 259272.

Moore, D.M. \& Reynolds, R.C. 1989. X-ray diffraction and the identification of clay minerals. Oxford University Press, NY. $332 \mathrm{p}$.

Mount, H.R., Newton, D.L., Räisänen, M.-L. \& Lee, S.E. 1995. Morphology of the soils in Central Finland. Soil Survey Horizons 36: 142-154.

Petäjä-Ronkainen, A., Peuraniemi, V. \& Aario, R. 1992. On podzolization in glaciofluvial material in northern Finland. Annales Academiae Scientiarum Fennicae, Series A III, Geologica-Geographica 156: 1-19.

Raulund-Rasmussen, K., Borggaard, O.K., Hansen, H.C.B. \& Olsson, M. 1998. Effect of natural organic soil solutes on weathering rates of soil minerals. European Journal of Soil Science 49: 397-406.

Righi, D., Räisänen, M.L. \& Gillot, F. 1997. Clay mineral transformations in podzolized tills in central Finland. Clay Minerals 32: 531-544.

Soil Survey Staff 1996. Soil survey laboratory methods manual. Soil survey investigation report no. 42. Version 3.0. USDA-SCS, National Soil Survey Center, Lincoln, NE. 693 p.

Soil Survey Staff 1999. Soil taxonomy. A basic system of soil classification for making and interpreting soil surveys. 2nd ed. Agriculture Handbook 436. U.S. Government Printing Office, Washington, DC.

Starr, M.R. 1991. Soil formation and fertility along a 5000 year chronosequence. Geological Survey of Finland Special Paper 9: 99-104.

Stobbe, P.C. \& Wright, J.R. 1959. Modern concepts of the genesis: podzols. Soil Science Society of America Proceedings 23: 161-164.

Stoops, G. 2003. Guidelines for analysis and description of 
Yli-Halla, M. et al. Formation of a cultivated Spodosol in East-Central Finland

soil and regolith thin sections. Soil Science Society of America, Madison, WI. 184 p.

Yli-Halla, M. \& Mokma, D.L. 1998. Soil temperature regimes in Finland. Agriculture and Food Science in Finland 7: 507-512.
Yli-Halla, M. \& Mokma, D.L. 2001. Soils in an agricultural landscape of Jokioinen, south-western Finland. Agricultural and Food Science in Finland 10: 33-43.

\title{
SELOSTUS
}

\section{Podsolimaannos karkealla hietamaalla Sotkamossa}

\author{
Markku Yli-Halla, Delbert L. Mokma, Lawrence P. Wilding ja Richard Drees \\ Maa-ja elintarviketalouden tutkimuskeskus, Michigan State -yliopisto ja Texas A\&M -yliopisto
}

Karkeille hietamaille syntyneet podsolit ovat Suomen kehittyneimpiä maannoksia. Niitä tutkimalla saadaan uutta tietoa tämän koko pohjoisella havumetsävyöhykkeellä yleisen maannostyypin kehittymiseen johtaneista prosesseista, joista edelleenkin vallitsee erilaisia käsityksiä. Tämän tutkimuksen kohteena oli Sotkamossa karkealla hietamaalla oleva noin 50 vuotta viljelty maa, joka on ollut kuivillaan noin 10700 vuotta. Muokkauskerroksen alapuolella oli huuhtoutumiskerros (valkomaa), joka sisälsi lähes pelkkää kvartsihiekkaa. Sen alapuolella oli noin $10 \mathrm{~cm}$ paksu rautapalsi eli iskostunut horisontti, johon ylempää orgaanisina kompleksiyhdisteinä huuhtoutuneet rauta ja alumiini ovat saostuneet. Mikroskoopilla voidaan nähdä, miten nämä saostuneet ainesosat peittävät kvartsihiekan jyväset ja sitovat ne yhteen. Tässä horisontissa oli erittäin runsaasti heikosti kiteytynyttä rautaoksidia, joka on uutettavissa ammoniumoksalaattiliuoksella, kun taas valkomaassa tällaista rautaa oli erittäin vähän. Rikastumiskerroksen alumiinista valtaosa oli pyrofosfaattiin uuttuvassa, oletettavasti orgaanisen aineksen sitomassa muodossa, mikä viittaa aineiden kulkeutuneen tähän horisonttiin nimenomaan kelaatteina eikä epäorgaanisina kolloideina. Syvä kyntö on nostanut valkomaata ja kappaleita rikastumiskerroksen iskostumasta myös muokkauskerrokseen. Rikastumiskerroksen alapuolella kvartsihiekkajyvästen pinnoilla ei ollut paljonkaan rautasaostumia, mutta mikroskoopilla näkyi runsaasti rapautumatonta biotiittia. Rikastumiskerroksen rauta lienee suureksi osaksi peräisin juuri biotiitista, joka on kokonaisuudessaan rapautunut pintamaasta. Vähemmän biotiittia sisältäviin maihin ei todennäköisesti kehity näin vahvaa rikastumiskerrosta maan pienemmän rautapitoisuuden takia. Podsoloituminen on luultavasti pysähtynyt sen jälkeen, kun maa on otettu viljelyyn ja sen pintaosien $\mathrm{pH}$ on kalkituksen seurauksena noussut. 